Ann. Biol. anim. Bioch. Biophys., 1976, 16 (3), 385-394.

\title{
DEVELOPMENTAL PATTERNS OF FOLLICLE-STIMULATING, LUTEINIZING AND THYROID-STIMULATING HORMONES IN THE HYPOTHYROID FEMALE RAT
}

\author{
M. UMEZU ('), J. M. CONS, and Paola S. TIMIRAS \\ Department of Physiology-Anatomy, \\ University of California, \\ Berkeley, California, 94720
}

\section{SUMMARY}

The developmental patterns of plasma and pituitary levels of the three glycoprotein hormones, FSH, LH and TSH, were studied in hypothyroidism and after thyroxine administration. Rats were radiothyroidectomized at birth and the pituitary and circulating hormone levels were measured at five-day intervals from 5 to 40 days of age by double-antibody radioimmunoassay. Body weight and weight of selected endocrine organs, and age of vaginal opening served as indices of growth and sexual maturation. In the controls, pituitary levels changed little with age, or increased slightly, plasma TSH, FSH and LH levels showed in these animals a peak at day I 2, I5 and 20 , respectively; this peak was followed by a decline and, in the case of TSH and $\mathrm{LH}$, a subsequent rise with age. In the hypothyroid rats, the patterns of all three hormones were significantly altered in plasma : TSH and LH levels were significantly higher at day 5 and continued to remain higher than controls until day $4 \circ$; FSH levels were significantly increased only at day 5. TSH and $\mathrm{LH}$ content of the pituitary was significantly elevated at day 30 and 35 . Replacement therapy with thyroxine returned to normal all of the foregoing alterations induced by hypothyroidism.

These findings suggest that the retardation in maturation induced by hypothyroidism and manifested by reduced growth and delayed vaginal opening is related to reduced ovarian function and to impaired steroid feedback to the central nervous system and to other body tissues.

\section{IN'TRODUC'TION}

It is well known that neonatal hypothyroidism affects the maturation of the central nervous system (CNS) (GEEL and TimiRAs, I967 $a$, I967 $b$; VALCANA and Timiras, I969 ; GoMEz, I97I ; Balazs et al., I97I ; DALAL et al., I97I ; Timiras, I972; VALCANA et al., I975) and, in turn, the development of certain endocrine functions (BAKKE, GELI,ER'T and LAWRENCE, I970). For example, in both male and female rats, early thyroid deficiency is associated with delayed growth and sexual

(1) Present address : Laboratory of Animal Reproduction, Faculty of Agriculture, Tohoku University Sendai (Japan). 
maturation. While we know that synthesis of growth hormone and prolactin (originating from the acidophil cells of the anterior pituitary) is decreased in hypothyroid animals (KIKUYAma et al., I974), less is known about the synthesis and release of the glycoproteins, FSH, LH and TSH (secreted from the basophil cells of the anterior pituitary) in these animals. The present study used radioimmunoassay techniques to compare the developmental patterns of circulating and pituitary FSH, IH and TSH levels in normal and hypothyroid female rats with and without administration of thyroxine. Inasmuch as sexual maturation involves changes in FSH and LH levels, and TSH levels are closely related to thyroid function, assessing the changes in these hormones in animals made hypothyroid in neonatal life may advance our understanding of CNS-endocrine development in normal and abnormal thyroid states.

\section{MATERIALS AND METHODS}

\section{Animals}

Long-Evans female rats were divided into two groups, each receiving a different diet : the controls received a powdered diet containing adequate ( $\mathrm{I} \mu \mathrm{g} / \mathrm{g}$ ) amounts of iodine and considered suitable for optimal growth of fetuses and of nursing pups. The experimental animals were fed a low-iodine $(0.1 \mu \mathrm{g} / \mathrm{g})$ diet during the last week of gestation and during the first six days of lactation to assure maximum uptake of ${ }^{131} \mathrm{I}$ administered at day $\mathrm{I}$ by the thyroid gland of the offspring ; after post partum day 6, they were returned to the same diet as that of the controls.

Control and hypothyroid offspring were killed at 5-day intervals, from birth until 40 days of age, for measurements of TSH, FSH and LH levels. Additional animals used for TSH determination were killed at day 12, and intact and hypothyroid animals injected with thyroxine were killed at days 5 and 25 only. In each age and experimental category studied, 5-12 animals were used.

\section{Experimental hypothyroidism}

Offspring of mothers placed on the regimen described above received a single intraperitoneal injection of $100 \mu \mathrm{C}$ of carrier-frue ${ }^{131} \mathrm{I}$ one day after birth. They displayed a severe degree of hypothyroidism, as described by GoLDBerg and CHAIKoff (I949) and repeatedly confirmed by many investigators.

\section{Thyroid treatment}

Both intact and hypothyroid rats were injected with thyroxine (sodium L-thyroxine, $0.05 \mathrm{ml} / 100 \mathrm{~g}$ body weight, $\mathrm{pH} 8.6$ ) according to two treatment schedules, in each case the efficiency of the dosage being based on maintenance of normal growth as jadged by body weight (GeEL and Timiras, I967 a). Animals to be killed on day 5 were injected from birth until sacrifice with $2.5 \mu \mathrm{g} / \mathrm{I}$ oo $\mathrm{g}$ body weight from day $\mathrm{I}$ to 3 and $5.0 \mu \mathrm{g} / \mathrm{I}$ oo $\mathrm{g}$ body weight for the $4^{\text {th }}$ and $5^{\text {th }}$ day. Animals to be killed on day 25 received a daily dose of $10.0 \mu \mathrm{g} / \mathrm{I} 00 \mathrm{~g}$ body weight initiated at day 6 and continued until sacrifice.

The controls for thyroxine-treated intact and hypothyroid animals received daily injections of the vehicle $(0.05 \mathrm{ml}$ saline solution/s oo $\mathrm{g}$ body weight, $\mathrm{pH} \mathrm{8.0-8.5)}$.

\section{Blood and pituitary collection}

After weighing, the animals were anesthetized with ether for less than one minute to collect blood. Pituitary and plasma samples were collected between noon and 3 p.m. Following centrifugation, the plasma was frozen until the time of assay. Pituitaries were weighed, sonified in $0.5 \mathrm{ml}$ of $0.9 \mathrm{p}$. I $00 \mathrm{NaCl}$ and frozen until assayed.

\section{Radioimmunoassay}

FSH, LH and TSH were assayed by double-antibody radioimmunoassay according to the directions supplied with the assay reagents obtained from the NIAMDD Rat Pituitary Hormone Program. The values were expressed in terms of NIAMDD-Rat-RP-I. 


\section{Statistics}

The significance of differences between groups was calculated by Student's $t$ test.

\section{RESULTS}

\section{Body and orgau weights}

As shown in figure $I$, body weight in control and hypothydroid animals was similar until day ro, when hypothyroid animals began to lag behind; body growth ceased after day 25 in hypothyroid rats. By day 40, for example, average body weight

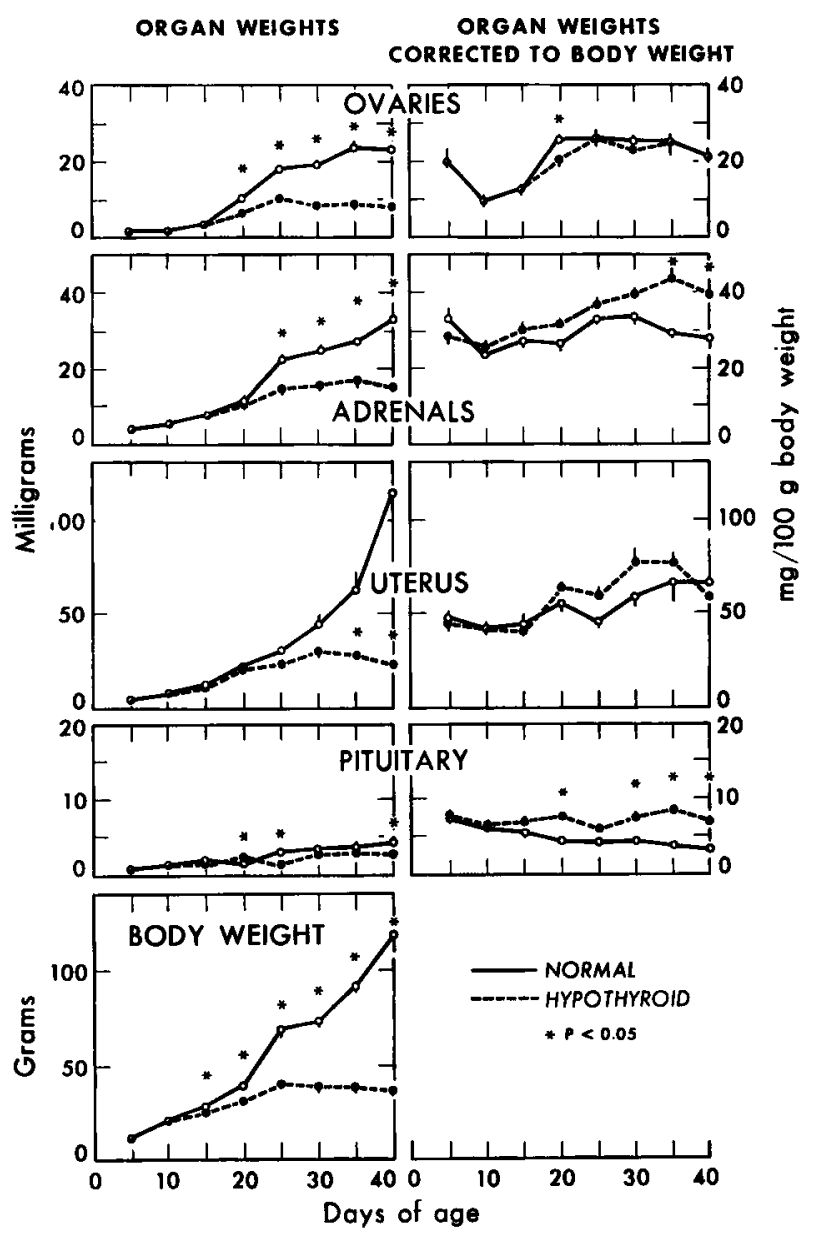

FiG. I. - Mean values of body and organ weights in normal (solid line) and hypothyroid (dotted line) female rats during development

Bracketed lines represent the Standard Error of the Mean;

the asterisk represents significance by $t$ test between normal and hypothyroid animals 
in controls was ro5.8 $\pm 3.0 \mathrm{~g}$ in contrast to $37.6 \pm 3.6 \mathrm{~g}$ in hypothyroid animalsa highly significant difference $(p<0.00 I)$. Thyroxine-treated hypothyroid animals (not illustrated here) showed normal weight curves.

Vaginal opening in control animals was evidenced in $2 / 9$ rats at day 35 and $3 / 6$ by day 40 , but not in any of the hypothyroid groups. (Vaginal opening in the Long-Evans rats occurs normally through day 45.) Delayed vaginal opening was accompanied by lower ovarian and uterine weight (fig. I) ; however, when these organ weights were calculated as percentage of body weight, the marked decrease in body size had the effect of obliterating the differences seen in the absolute weight. In the case of adrenal and pituitary, weights were significantly higher at most ages (fig. I).

In the hypothyroid animal given replacement therapy, organ weights were similar to those of controls. Intact animals treated with thyroxine showed no differences from controls either in body or organ weight, and thus no data are given here for either of these groups.

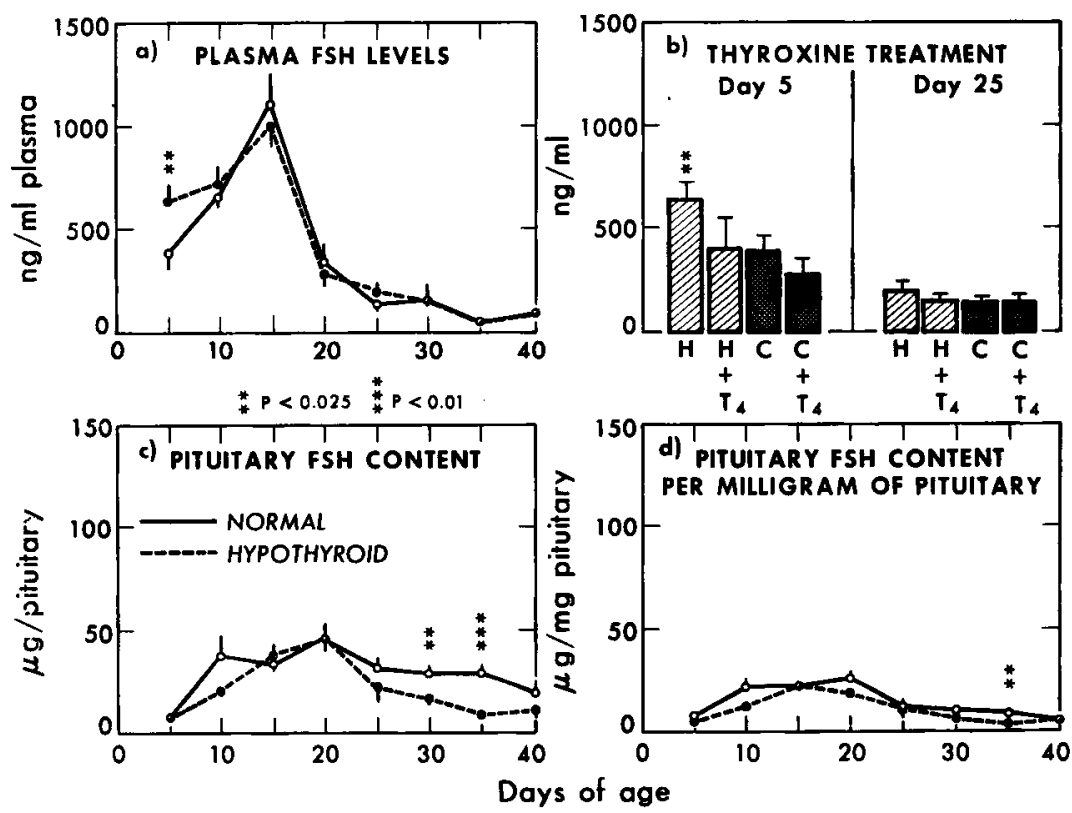

FIG. 2. - Plasma and pituitary levels of FSH in normal and hypothyroid rats

a) mean plasma levels with increasing age ;

b) mean plasma levels of hypothyroid and normal rats injected with thyroxine; rats were killed at day 5 and $25\left(\mathrm{H}\right.$ : hypothyroid; $\mathrm{H}+\mathrm{T}_{4}$ : hypothyroid rats receiving thyroxine replacement therapy ; $\mathrm{C}$. : normal control ; $\mathrm{C}+\mathrm{T}_{4}$ : normal rats receiving thyroxine treatment) ;

c) pituitary content with increasing age;

d) pituitary content per mg tissue with increasing age.

Bracketed lines represent Standard Error of the Mean; the asterisks represent the significance by $t$ test between control and experimental animals.

\section{Plasma and pituitary levels of FSH}

As illustrated in figure $2 a$, plasma FSH levels were significantly higher in hypothyroid rats at day 5 . In the days following, however, the plasma FSH pattern was 
similar in experimental and control groups and both groups showed a significant peak at day 15 . FSH levels in thyroxine-treated animals were comparable to control values at day 5 and day 25 (fig. $2 b$ ).

FSH content in the whole pituitary was found to be generally lower in the developing hypothyroid rats, although when values were expressed as $\mu \mathrm{g} / \mathrm{mg}$ pituitary, the resulting curve was similar in experimental and control animals except at day 35 when it was significantly lower (fig. $2 c, d$ ).

\section{Plasma and pituitary levels of $L H$}

In controls, plasma $\mathrm{LH}$ levels increased with age showing the highest value at 20 days followed by a decrease prior to the onset of puberty and a progressive increase from day 30 to 40 . Plasma $\mathrm{LH}$ levels were significantly higher in hypothyroid rats from day 5 and, unlike controls, remained constantly high until day 40 (fig. $3 a$ ).

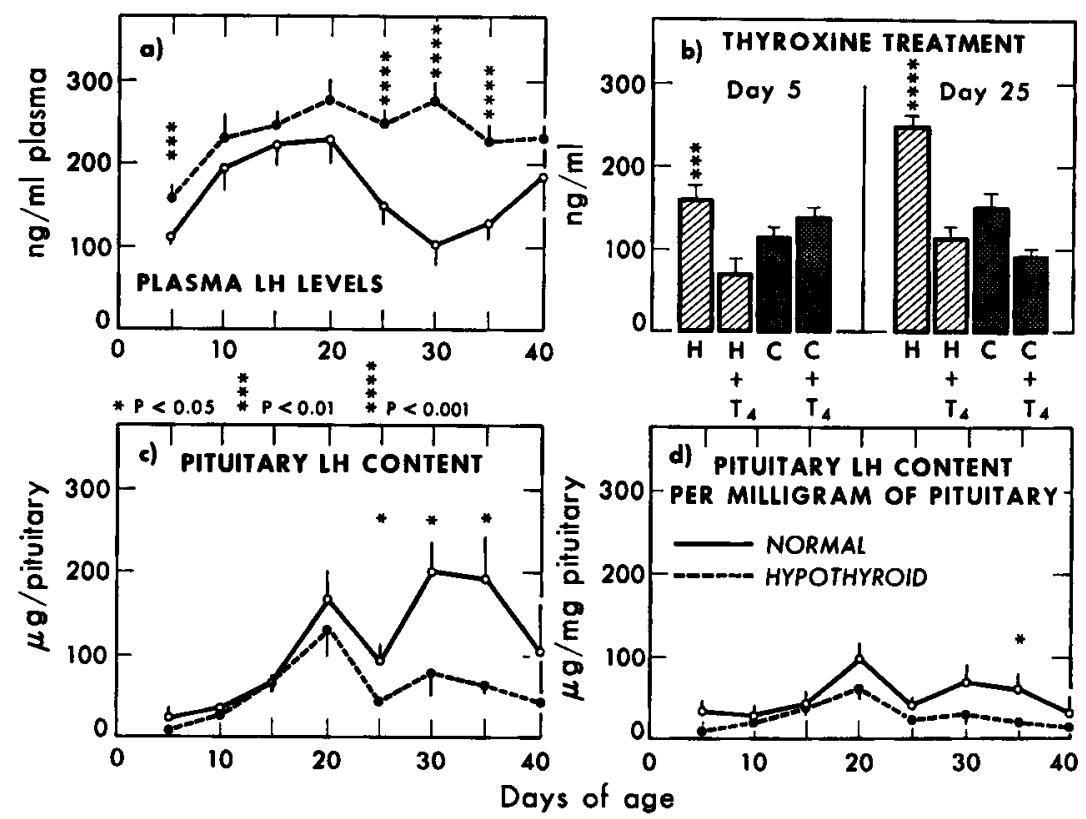

FIG. 3. - Plasma and pituitary levels of LH in normal and hypothyroid rats

a) mean plasma levels with increasing age ;

b) mean plasma levels of hypothyroid and normal rats injected with thyroxine; rats were killed at day 5 and 25 ( $H$ : hypothyroid; $H+T_{4}$ : hypothyroid rats receiving thyroxine replacement therapy; $\mathrm{C}$ : normal control; $\mathrm{C}+\mathrm{T}_{4}$ : normal rats receiving thyroxine treatment);

c) pituitary content with increasing age ;

d) pituitary content per mg tissue with increasing age.

Bracketed lines represent Standard Error of the Mean ; the asterisks represent the sigmificance by $t$ test between control and experimental animals.

At day 5, thyroxine administration did not affect $\mathrm{LH}$ levels in intact animals but returned towards normal the elevated levels of the hypothyroid rats ; at 25 days, thyroxine decreased LH levels in hypothyroid and to a lesser degree in intact animals (fig. $3 b$ ). 
LH content in the whole pituitary gradually increased from day 5 to 20 in hypothyroid and control groups, but subsequently decreased significantly in the hypothyroid group in contrast to controls which maintained high levels throughout the experimental period (fig. $3 c, d$ ). When values were expressed as $\mu \mathrm{g} / \mathrm{mg}$ pituitary, the general pattern was similar between control and hypothyroid animals, but levels were depressed in hypothyroid rats, a significant reduction being apparent only at day 35 .

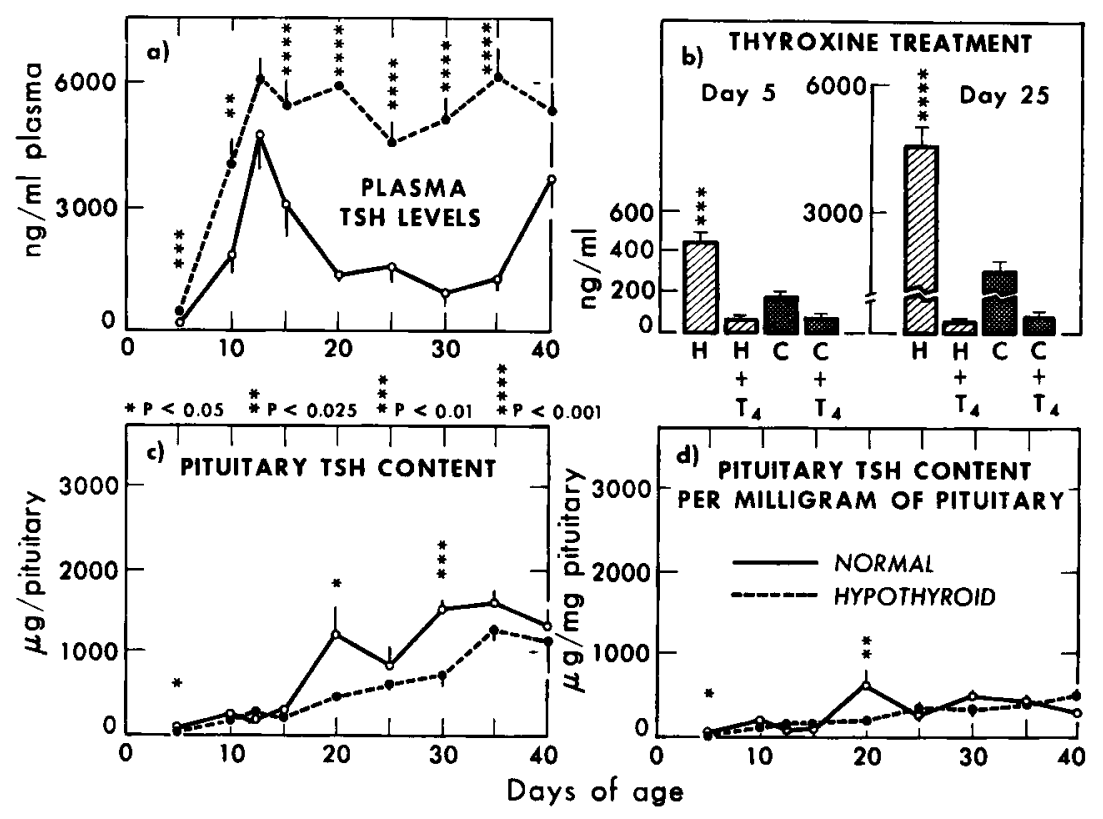

FIG. 4. - Plasma and pituitary levels of TSH in normal and hypothyroid rats

a) mean plasma levels with increasing age;

b) mean plasma levels of hypothyroid and normal rats injected with thyroxine; rats were killed at day 5 and $25\left(\mathrm{H}\right.$ : hypothyroid; $\mathrm{H}+\mathrm{T}_{4}$ : hypothyroid rats reveiving thyroxine replacement therapy; $\mathrm{C}$ : normal control; $\mathrm{C}+\mathrm{T}_{4}$ : normal rats receiving thyroxine treatment);

c) pituitary content with increasing age ;

d) pituirary content per mg tissue with increasing age.

Bracketed lines represent Standard Error of the Mean ; the asterisks represent the significance by $t$ test between control and experimental animals.

\section{Plasma and pituitary levels of TSH}

The present data confirm our previous findings that plasma TSH levels are markedly higher in developing hypothyroid rats than in controls from days 5 to $4^{\circ}$ (fig. $4 \mathrm{a}$ ). Both groups that received thyroxine treatment showed considerably lower plasma TSH levels at day 5 and particularly at day 25 than both hypothyroid and intact controls (fig. $4 \mathrm{~b}$ ). Pituitary levels of TSH were generally lower in the hypothyroid animal as compared to controls (fig. $4 c, d$ ). 


\section{DISCUSSION}

The plasma and pituitary developmental patterns of the three hormones measured in female rats corroborate previous findings; thus, whereas pituitary levels change little with age or only slightly increase (RAMIREZ and SAWYER, I965; MOORE, I966; KRAGT and GANONG, I968; FAWKE and BROWN, I970), plasma FSH and LH levels show a peak at days I5 and 20, respectively, and then decline ; for $\mathrm{LH}$, this decline is followed by a subsequent rise accompanying the onset of puberty (CALIGARIS, AstradA and 'TALEISNIK, I97I ; KRAGT and Dahl,GREN, I972 ; OJEDA and Ramirez, I972; Caligaris, Astrada and Taleisnik, I973 ; MeIJSRoElofs et $a l$, I973 $a$, I973 $b$; DöHLER and WuTTKE, I974; Cons and TIMIRAS, in press). TSH levels peak at day $\mathrm{I} 2$, then decline to increase slowly with age (CoNs, UMEZU and Trmiras, I975). In the hypothyroid rats the patterns of all three hormones in plasma are altered, but the alterations differ with respect to the severity of the change and the age when it occurs. For example, TSH and LH plasma levels are significantly higher in hypothyroid animals at 5 days and continue to remain higher than control values until 40 days; on the other hand, FSH plasma levels are little changed by hypothyroidism except at day 5 when they are elevated. That these changes are to be related primarily to hypothyroidism and not to other factors (e.g., radioactivity from ${ }^{131}$ I or hyponutrition) is demonstrated by the reversal of all alterations observed induced by thyroxine replacement therapy.

The existence and competence of a pituitary-thyroid axis during early postnatal development, and its failure to develop in hypothyroidism, have been discussed previously (Cons, UMEzU and TImrRas, I975). Similarly, a pituitary-gonad axis seems to mature early during development (CALIGARIS, ASTRADA and TAIEISNIK, I97I ; KRAG'I and DAHLGREN, I972 ; CALIGARIS, ASTRADA and TALEISNIK, I973 ; MEIJS-RoELoFs et al., I973 $a$, I973 $b$ ), but in which manner its development may be influenced by levels of thyroid hormones remains to be explained. Elevated gonadotropin levels were reported in the adult rat after thyroidectomy (LAROCHELLE and FREEMAN, I974). Inasmuch as small ovarian and uterine weights can be taken as manifestations of delayed ovarian development (UMEZU, I970 ; REITER et al., I972 ; MEIJS-ROELOFs et al., I973 $a, \mathrm{r} 973 b$ ) it is possible to speculate on the basis of the reduced size of the ovary and uterus of the hypothyroid rats that an early deficiency of thyroid hormones delays ovarian maturation. The consequent changes in ovarian hormone secretion could lead the pituitary to decrease its production (as suggested by the significant decrease of pituitary content of FSH and $\mathrm{LH}$ at days 30 and 35 ) and be related to the altered secretion of gonadotropins.

According to an alternate hypothesis, the delayed maturation of the brain as a whole induced by hypothyroidism (TIMrRAS, I972) would also be reflected in alterations in developmental patterns of gonadotropin secretion. We know, for example, that in the rat the hypothalamic-hypophyseal system undergoes rapid development from day 5 to 40 (GLYDoN, I957) and that the critical time for the maturational effects of thyroid hormones on the brain is between day 8 and I2 (GEEL, and Timiras, I967 $a, \operatorname{Ig} 67 b$ ).

The consequences of altered gonadotropic development in the hypothyroid

Annales de Biologie animale. - I976. 
rats with respect to gonadal function and steroid feedback should be studied more extensively. In the present experiments, the retardation of vaginal opening in the hypothyroid rats testifies to a delay in the onset of puberty. Even though by day $40 \mathrm{FSH}$ and $\mathrm{LH}_{\mathrm{H}}$ levels are essentially normal, the alterations in their patterns at a critical age during pre-pubertal development may be sufficient to induce longlasting effects on sexual maturation. Indeed, it is possible that abnormalities in the ratio of the gonadotropins in the developing animal may be sufficient to account for delayed vaginal opening in hypothyroid rats. In fact, an altered gonadotropic ratio during pre-pubertal development has been found to occur under adverse environmental conditions such as rearing of animals in darkness (Cons and TrmiRAS, I975, in press or under chronic hypoxia (BRoTMAN, UMEZU and CoNS, 1975) and may be associated with the subsequent disturbances in sexual function reported in these animals.

It is well known that replacement therapy with thyroxine reverts to normal the physical and metabolic alterations induced by hypothyroidism; this is the case also in the present experiments. Of particular interest is that, with respect to TSH, thyroxine administration not only reduces its abnormally elevated levels in hypothyroid animals, but also decreases the normal levels displayed by the intact (control) animals. Furthermore, this inhibitory feedback of thyroxine is already present at 5 days of age, an indication that the inhibitory hypothalamo-hypophysealthyroid feedback is already operative at this early age. On the other hand, FSH and particularly $\mathrm{L}_{\mathrm{H}}$ plasma levels, even though markedly affected by hypothyroidism seem to respond to thyroxine administration only when abnormally elevated (as in hypothyroid rats) and not when normal (as in intact controls). Because of the early establishment of the negative feedback mechanisms reported by us and others and because of the relative toxicity of thyroxine in young rats (EAYRs, rg64; EAYRS and HolmEs, I964 ; PELTON and BASS, I973), it is difficult to reproduce satisfactorily a hyperthyroid state in the developing animal. Therefore, it remains to be investigated further whether doses of thyroxine higher than those used in the present study could significantly modify gonadotropin levels and, in turn, also accelerate the maturation of those aspects of sexual function that are under hormonal control.

Sexual Maturation, 3rd Workshop August 31, September 3, 1975.

\section{ACKNOWLEDGEMENTS}

This work was supported by NIH Grant HD o7340.

The authors thank Dr T. Valcana for her sound advice in the planning and execution of the experiments.

The authors also acknowledge the gift of rat-FSH, LH and TSH radioimmunoassay materials from the Rat Pituitary Hormone Distribution Program of the National Institute of Arthritis, Metabolism and Digestive Diseases. 


\section{RÉSUMÉ}

\section{ÉVOLUTION POSTNATALE DES HORMONES GONADOTROPES (FSH ET L,H) ET THYRÉOTROPES (TSH) CHEZ IA RATTE HYPOTHYROÏDIENNE}

L'évolution postnatale des hormones hypophysaires LH, FSH et TSH a été étudiée entre 5 et 40 jours chez des rattes thyroïdectomisées à la naissance par injection d'iode radioactif, avec ou sans supplémentation par de la thyroxine. Les hormones sont dosées à intervalles réguliers par une méthode radioimmunologique. La croissance et la maturation sexuelle estimée par l'âge à l'ouverture vaginale sont ralenties chez les rattes thyroïdectomisées. Chez les rattes témoins les trois hormones augmentent avec l'âge et atteignent un maximum dans le plasma vers Io jours pour la TSH, I 6 jours pour la FSH et 20 jours pour la LH. Chez les rattes thyroïdectomisées les niveaux de TSH et LH sont significativement plus élevés que chez les témoins à 5 jours et le restent jusqu'à $4^{\circ}$ jours. Le niveau de $\mathrm{FSH}$ n'est significativement augmenté qu'à 5 jours. L'administration de thyroxine ramène les taux d'hormones circulantes au niveau normal, en particulier le taux de TSH, ce qui suggère que le rétrocontrôle hypothalamus-hypophyse-thyroïde est déjà en place chez la ratte de ro jours.

Ces résultats indiquent que le fonctionnement normal de la thyroïde dans la période néonatale est indispensable pour la croissance et la maturation sexuclle normales chez la ratte.

\section{REFERENCES}

BAKKe J. L., GELIERT K. J., LAWRENCE N. L., I970. The persistent effects of perinatal hypothyroidism on pituitary, thyroidal and gonadal functions. J. Lab. Clin. Med., 76, 25-33.

Balázs R., Cocks W. A., EAyrs J. T., Kovacs S., I97I. Biochemical effects of thyroid hormones on the developing brain, 357-379, in : HaMBURGH M., BARRINGTON E. J. W., Hormones in development. Appleton-Century-Crofts, New York.

Brotman S., Lmezu M., Cons J. M., 1975. Developmental pattern of gonadotropins and hypothalamic monoamines under normal and stressful environmental conditions. 6th Internat. Congr. Internat. Soc. Psychonettroendocrinology. (Aspen, Colorado, August 22-26, 1975).

Caligaris L., Astrada J. J., Taleisnik S., r97I. Influence of age on the release of luteinizing hotmone induced by cestrogen and progesterone in immature rats. J. Endocr., 55, 97-103.

Caligaris L., Astrada J. J., Taleisnik S., I973. Development of the mechanisms involved in the facilitatory and inhibitory effects of ovarian steroids on the release of follicle-stimulating hormone in the immature rat. J. Endocr., 58, 547-554.

Cons J. M., TImiras P. S., r975. Developmental patterns of FSH and LH in female rats deprived of light before puberty. Environ. Physiol. Biochem. (to be published in the December issue).

Cons J. MI., LMezU M., TImiras P. S., r975. Developmental patterns of pituitary and plasma TSH in the normal and hypothyroid female rat. Endocrinology, 97, 237-240.

Dalal K. B., Valcana T., Timiras P. S., Einstein E. R., I97I. Regulatory role of thyroxine on myelinogenesis in the developing rat. Neurobiology, 1, 21 I-224.

Döhler K. D., WuTtke W., I974. Serum LH, FSH, prolactin and progesterone from birth to puberty in female and male rats. Endocrinology, 94, 1003-1008.

EAYRS J. T., 1964. Effect of neonatal hyperthyroidism on maturation and learning in the rat. Anim. Behav, 12, 195-199.

Eayrs J. T., Holmes R. L., I964. Effect of neonatal hyperthyroidism on pituitary structure and function in the rat. J. Endocr., 29, 7I-8I.

FAw Ke L., Brows P. S., I97o. Pituitary content of follicular stimulating hormone in the female rat J. Reprod. Fert., 21, 303-312.

Geel S. E., Timiras P.S., I967 a. Influence of neonatal hypothyroidism and of thyroxine on the acetylcholinesterase and cholinesterase activities in the developing, central nervous system of the rat. Endocrinology, 80, 1069-1074.

GEEL S. E., Timiras P. S., I967 $b$. The influence of neonatal hypothyroidism and of thyroxine on the ribonucleic acid and deoxyribonucleic acid concentrations of rat cerebral cortex. Brain Research, 4, $135-142$. 
Grydon R. ST. J., I957. The development of the blood supply of the pituitary in the albino rat, with special reference to the portal vessels. J. Anat. (London), 91, 237-244.

Goldberg R. C., ChaikofF I. L., r949. A simplified procedure for thyroidectomy of the newborn rat without concomitant parathyroidectomy. Endocrinology, 45, 64-70.

Gomez C. J., r97. Hormonal influences of the biochemical diffenrentiation of the rat cerebral cortex. 4I7-435, in : Hamburgh M., Barrington E. J. W., Hormones in development, Appleton-Crofts, New York.

Kikuyama S., Nagasawa H., Yanai R., Yamanouchi K., 1974. Effect of perinatal hypothyroidism on pituitary secretion of growth hormone and prolactin in rats. J. Endocr., 62, 213-223.

KRAGT C. L., DAhtgren J., I972. Development of neural regulation of follicular stimulating hormone secretion. Neuroendocrinology, 9, 30-40.

Kragt C. L., Ganong W. F., I968. Pituitary FSH content in female rats at various ages. Endocrino$\log y, 82, \mathrm{I} 24 \mathrm{I}-\mathrm{I} 244$.

Larochelle JR. F. T., Freeman M. E., 1974. Superimposition of thyroid hormone regulation on gonadotropin secretion. Endocrinology, 95, 379-387.

Meijs-Roelofs H. M. A., Uilenbroek J. T. J., De Jong F. H., Weischen R., I973a. Plasna oestradiol-17 $\beta$ and its relationship to serum follicle stimulating hormone in imnature fermale rats J. Endocr., 54, 295-304.

Meijs-Roelofs H. M. A., Uilenbroek J. T. J., Osman P., Welschex R., I973 $b$. Serum levels of gonadotropins and follicular growth in prepubertal rats, 3 -II, in : Perers $H$. , The development and maturation of the ovary and its functions, Excerpta Medica, ICS, Amsterdam.

Moore W. W., I965-rg66. Changes in pituitary LH concentration in prepubertal and postpubertal rats. Neuroendocrinology, 1, 333-340.

Ojeda S. R., Ramirez V. D., I972. Plasma level of LH and FSH in maturing rats : response to hemigonadectomy. Endocrinology, 90, 466-472.

Pelton E. W., Bass N. H., I973. Adverse effects of excess thyroid hormone on the maturation of rat cerebrum. Arch. Neurol., 29, $145-150$.

Ramirez V. D., Sawyer C. H., I965. Advancement of puberty in the female rat by estrogen. Endocrinology, 74, $1158-1168$.

Reiter E. O., Goldenberg R. L., Vaitukaitis, G. L., Ross, G. T., r972. A role for endogenonis estrogen in normal ovarian development. Endocrinology, 91, 1537-1539.

Timiras P. S., I972. Development and plasticity of the nervous system, I29-I65, in : TiMiras P. S., Developmental Physiology and Aging. Macmillan, New York.

UmezU M., I970. The basal observations on puberty in female rats. The changes in weight of ovaries and uterus and the development of ovarian follicles. Jap. J. Anim. Reprod., 16, 71-76.

Valcana T., Einstein E. R., Csejtey J., Dalal K. B., Timiras P. S., I975. Influence of thyroid hormones on myelin proteins in the developing rat brain. J. Neurol. Sci., 25, I9-27.

Valcana T., Trmiras P. S., I969. Effect of hypothyroidism on ionic metabolism and Na-K activated ATP phosphohydrolase activity in the developing rat brain. J. Netrochemistry, 16, 935-943. 